\title{
Konstruk Nilai Moral Anak Usia Dini Versi Guru PAUD
}

\author{
Amir Syamsudin ${ }^{1}$, Harun ${ }^{1}$, Joko Pamungkas ${ }^{1}$, Sudaryanti ${ }^{1}$, Prayitno $^{1}$ \\ Pendidikan Guru Pendidikan Anak Usia Dini, Universitas Negeri Yogyakarta, Indonesia(1) \\ DOI: $\underline{10.31004 / o b s e s i . v 6 i 3.1883}$
}

\begin{abstract}
Abstrak
Pencegahan perilaku tidak bermoral generasi muda dapat dilakukan sejak usia dini. Stimulasi perkembangan moral anak oleh guru dan pengukuran capaian perkembangannya memerlukan instrumen yang valid dan reliable. Tujuan penelitian ini untuk mengonfirmasi kajian teoritik indikator amatan perkembangan moral anak usia dini dalam persepsi guru. Teknik analisis data menggunakan statistik deskriptif dan exploratory factor analyses indikator teramati terhadap variable latent moral anak dengan menggunakan software Smart-PLS versi 3.8.2. Nilai moral anak usia dini terdiri dari adaptasi, disiplin, jujur, percaya diri, peduli, santun, tanggung jawab, dan toleran. Adaptasi anak itu bergaul dengan teman sebaya atau diterima dalam lingkungan pertemanan baru. Disiplin itu mengendalikan diri anak dalam proses interkasi sosial. Substansi kejujuran itu bercerita, berbuat, dan menilai sesuatu apa adanya. Percaya diri dicirikan oleh inisiatif dan berbagi pengalaman belajar dengan teman lain. Anak-anak yang berbagi makanan/alat belajar dengan teman lain adalah inti peduli. Kesantunan terletak pada komunikasi yang produktif antara anak dengan guru. Tanggung jawab diamati melaui aktivitas anak merapikan alat setelah digunakan. Penghargaan anak terhadap karya teman lain menjadi penanda anak terbuka dengan kenyataan yang berbeda dengan dirinya.
\end{abstract}

Kata Kunci: moral; indikator amatan; anak usia dini.

\begin{abstract}
Prevention of immoral behavior of the younger generation can be done from an early age. Stimulation of children's moral development by teachers and measuring their developmental achievements require valid and reliable instruments. The purpose of this study was to confirm the theoretical study of the observed indicators of early childhood moral development. The data analysis technique used descriptive statistics. Perform exploratory factor analysis on the observed indicators of latent variables, specifically for data on children's moral development using Smart-PLS version 3.8.2 software. The moral values of early childhood consist of adaptation, discipline, honesty, confidence, caring, courtesy, responsibility, and tolerance. The adaptation of the child to get along with peers or be accepted in a new circle of friends. Discipline controls the child's self in the process of social interaction. The substance of honesty is telling, doing, and judging something as it is. Selfconfidence is characterized by initiative and sharing learning experiences with other friends. Children sharing food/learning tools with other friends is the essence of caring. Politeness lies in productive communication between children and teachers. Responsibility is observed through the activity of children tidying up tools after use. The child's appreciation for the work of other friends becomes a sign that the child is open to a reality that is different from his own.
\end{abstract}

Keywords: moral; observable indicator; early years

Copyright (c) 2021 Amir Syamsudin

$\triangle$ Corresponding author :

Email Address : amirsyamsudin@uny.ac.id (Sleman, Yogyakarta, Indonesia)

Received 26 June 2021, Accepted 16 November 2021, Published 24 November 2021 


\section{PENDAHULUAN}

Masalah yang dihadapi anak usia dini bersumber dari lingkungan anak dan bawaan lahirnya (Ratu Balqis, 2021). Secara garis besar permasalahan anak meliputi masalah makro dan mikro. Jenis-jenis masalah makro diantaranya penelantaran anak oleh orang tua, salah asuhan, korban perceraian orang tua, korban kekerasan orang tua, dan atau anak tumbuh di lingkungan yang tidak aman secara sosial maupun emosional. Jenis masalah mikro diantaranya gangguan perkembangan kognitif, emosi, motoric, dan perilaku sosial. Masalah mikro ini salah satu penyebab pembelajaran anak usia dini kurang berhasil.

Faktor-faktor yang mempengaruhi gangguan belajar anak adalah masalah fisik, psikis, dan lingkungan (Wijaya, 2020). Masalah fisik misalnya cacat sejak lahir, asupan gizi, kondisi kesehatan, dan kelelahan fisik. Masalah psikis misalnya kecerdasan, daya ingat, daya juang, dan pengelolaan emosi anak. Masalah lingkungan misalnya pola interaksi dalam keluarga, sekolah, masyarakat, dan media sosial. Kecenderungan masalah yang dihadapi anak usia dini adalah perundungan.

Perundungan merupakan perilaku menyakiti orang lain secara verbal maupun fisik dan memiliki tingkat kepuasan emosional tertentu bagi pelaku jika melakukan perundungan (Hidayati \& Widyana, 2021). Korban perundungan tidak berdaya untuk menolak perlakuan buruk dari pelaku karena takut. Perilaku perundungan dapat terjadi pada semua anak di daerah mana pun. Peneliti menemukan gejala-gejala ini di daerah yang jauh dari pusat pemerintahan seperti daerah pesisir selatan Gunung Kidul.

Gunung Kidul merupakan satu dari lima kabupaten/kota di Provinsi Daerah Istimewa Yogyakarta. Wilayah pemerintahan Gunung Kidul terdiri atas 144 desa yang dibagi menjadi 18 wilayah kecamatan. Sisi selatan Gunung Kidul berbatasan dengan Samudera Hindia dengan garis pantai sepanjang $65 \mathrm{~km}$ dari arah timur ke barat, yaitu dari kecamatan Girisubo sampai dengan kecamatan Purwosari. Potensi wisata pantai dan potensi ekonomi pertanian tadah hujan serta penambangan batu dan pasir sangat besar. Jumlah penduduk Gunung Kidul sebanyak 702.104 jiwa berdasarkan data sensus penduduk tahun 2014 (BPKP, 2021). Dua dari 18 kecamatan yang menjadi lokasi penelitian adalah kecamatan Rongkop dan Saptosari.

Kabupaten Gunung Kidul memiliki 669 Taman Kanak-kanak, dan 623 lembaga PAUD non-TK. 18 Lembaga TK milik pemerintah dan 651 lembaga lainnya milik swasta (Disdikpora, 2021). TK yang sudah terakreditasi sedikit, guru yang bersertifikat pendidik juga sedikit, kondisi sarana prasarana sekolah yang serba terbatas, dan jumlah anak yang berpartisipasi/bersekolah di TK juga sedikit. Keluhan yang sering disampaikan para pendidik adalah kesulitan dalam melakukan penilaian perilaku anak.

Pencegahan perilaku perundungan terhadap orang lain dapat dilakukan sejak dini. Ada ruang pembelajaran nilai agama dan moral bagi anak usia dini. Peran guru dalam membelajarkan anak tentang nilai-nilai moral sangat strategis dan sekaligus memberi fondasi perilaku moral pada jenjang Pendidikan berikutnya.

Nilai agama dan moral anak usia dini mencakup ibadah sehari-hari dan perilaku baik. Ibadah sehari-hari meliputi do'a, hafalan kitab suci, dan ritual keagamaan. Do'a yang dipraktikkan anak sangat dekat dengan kehidupan nyata seperti do'a makan, minum, berpakaian, mandi, keluar rumah/masuk rumah, berdo' a untuk kedua orang tua, do'a buka puasa, dan do'a talbiyah haji (Soleh, 2018). Hafalan kitab suci meliputi ayat pendek, hadis, dan niat ibadah ritual. Ritual keagamaan yang dilakukan adalah shalat sunat dhuha, wudhu, tayamum, dan makanan halal (Mumtaza, 2018).

Perilaku baik sehari-hari yang dipraktikan anak meliputi adaptasi, disiplin, sabar, santun, peduli, percaya diri, tanggung jawab, toleransi, jujur, dan mandiri (Peraturan Menteri Pendidikan \& Kebudayaan RI Tentang Kurikulum 2013 Pendidikan Anak Usia Dini, 2014). Adaptasi merupakan kemampuan anak menyesuaikan diri dengan lingkungan fisik maupun non fisik (Amaliah \& Prasetyo, 2021). Adaptasi dapat dideskripsikan bahwa anak merespon segala sesuatu yang ada di lingkungannya dengan mengucap dan menjawab salam, bersalaman, bermain dengan teman sebaya, berbagi alat tulis, menolong teman ketika 
kesulitan, menghargai hak milik, pendapat, dan hasil karya orang lain, serta mampu mengekspresikan berbagai bentuk perasaan seperti senang dan antusias (Meinarno, E, 2011).

Disiplin merupakan perilaku anak melakukan kegiatan sesuai dengan aturan dan instruksi yang diberikan oleh guru maupun dalam rutinitas (kebiasaan) yang ada didalam kelas ataupun lingkungan sekolah (Aulina, 2013).

Jujur dapat ditandai dengan anak meminta izin ketika meminjam barang dan mengembalikan barang yang dipinjam serta tidak membawa pulang mainan yang bukan miliknya (Azizah, R.; Putri, N. R.; Rahmadini, T. A.; \& Lokeswara, 2019). Pembiasaan positif seperti jujur sejak anak usia dini menjadi pondasi pengembangan karakter pada jenjang pendidikan berikutnya (Ansori, 2021).

Percaya diri merupakan kemampuan untuk berekspresi sesuai dorongan batin anak dan bertanggungjawab atas pilihannya tersebut (Fransisca et al., 2020). Percaya diri anak dapat dideskripsikan dengan anak berinisiatif dan berani untuk menceritakan pengalaman, pendapat, hasil karya dan menjawab pertanyaan yang diberikan. Anak dapat mengerjakan tugas dengan optimis, dan mudah berinteraksi dengan teman sebaya atau orang yang berada di lingkungannya (Fransisca et al., 2020).

Sabar merupakan perilaku anak dapat mengendalikan keinginan dan emosi. Kesabaran dapat dilatih secara bertahap melalui praktik pembiasaan (Ghozali, 2021). Hal ini dapat dilihat dari pembiasaan anak mau menunggu giliran untuk bersalaman dengan guru, antri menempatkan sepati di rak, dan antri saat akan mencuci tangan (Lombu \& Suprihatin, 2020).

Santun terhadap diri sendiri, orang lain, dan lingkungan merupakan lingkup hubungan prososial anak. Salah satu bentuk kesantunan itu adalah berbahasa yang sopan kepada orang tua, guru, dan teman sebaya (Apriliani et al., 2020). Santun merupakan perilaku anak berkomunikasi harmonis dengan lingkungannya. Kesantunan akan memberikan rasa nyaman kepada orang lain dan akan berdampak juga kepada diri sendiri (Putrihapsari \& Dimyati, 2021).

Peduli merupakan perilaku anak menawarkan bantuan, berbagi makanan/barang kepada orang lain. anak membuang sampah pada tempatnya, membedakan sampah organik dan anorganik, menyapu lantai, menggunakan air secukupnya, menyiram tanaman dan menghemat energi (Masrukhan, 2016).

Tanggungjawab adalah kemampuan anak untuk menaati aturan sosial secara sukarela untuk kemasalahatan diri sendiri, orang lain, dan lingkungan (Nugroho \& Mawardi, 2021). Tanggung jawab anak usia dini dapat ditandai dengan anak secara mandiri menggantungkan tas pada tempatnya, merapikan alat mainan setelah selesai bermain, bersedia merapikan alat belajar dan alat makan dengan rapi setelah digunakan, timbul kemauan dan inisiatif untuk membersihkan tangan sebelum dan sesudah makan sesuai aturan, bersedia membersihkan sisa makanan apabila berceceran di sekitar tempat makan, serta bersedia membuang sampah bungkus makanan ke dalam tong sampah (Halimatussadiah et al., 2017).

Toleransi dapat ditandai dengan anak bersedia untuk bermain bersama teman-teman mereka yang berasal dari semua kalangan tanpa pilih-pilih, tidak memaksakan kehendak pribadi, bersedia mendengarkan dan menerima pendapat orang lain (Fuad, 2015).

\section{METODOLOGI}

Alur penelitian terdiri dari (1) merumuskan definisi konseptual - definisi operasional - indikator perilaku moral; (2) telaah keterbacaan instrumen oleh pengguna; (3) pengumpulan data penelitian; (4) tabulasi dan analisis data; dan (5) pelaporan hasil penelitian. 


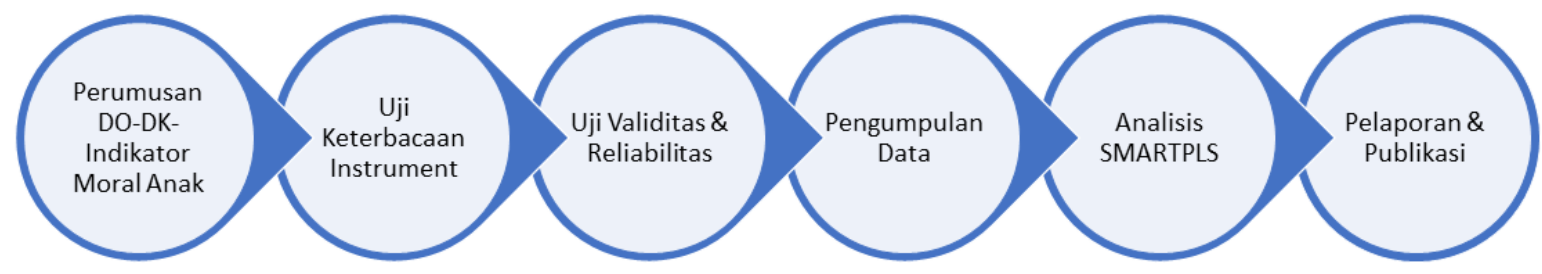

Gambar 1. Alur Penelitian Konstruksi Moral

Data dikumpulkan dengan cara self-assessment di setiap akhir sesi pelatihan dengan mengikuti standar protokol kesehatan Covid-19. Subjek penelitian sebanyak 220 orang guru di wilayah Saptosari dan Rongkop Gunung Kidul. Instrument self-assessment berisi persepsi guru tentang indikator teramati capaian perkembangan nilai moral anak usia dini.

Rancangan penelitian ini survey stimulasi nilai moral anak melalui permainan gamelan cilik dan kriya tanah liat. Guru melakukan permainan gamelan cilik dan praktik kriya tanah liat selama 60 menit. Kelompok seni kriya tanah liat berjumlah 20 orang, demikian juga kelompok permainan gamelan cilik berjumlah 20 orang. Waktu pengambilan data dilakukan selama lima hari berturut-turut dan setiap hari berbeda pesertanya. Setelah permainan selesai, setiap guru melakukan self-assessment terhadap kemampuan merefleksikan nilai-nilai moral yang muncul dari kedua permainan tersebut.

Subjek penelitian ini guru pendidikan anak usia dini di wilayah pesisir selatan pantai Gunung Kidul, tepatnya di kecamatan Saptosari dan Rongkop. Karakteristik subjek penelitian adalah guru yang telah bekerja di atas 5 tahun dan bersedia menjadi responden secara sukarela. Jenis data yang dikumpulkan dalam penelitian ini berupa persepsi guru tentang indikator teramati dari perkembangan nilai moral anak.

Teknik analisis data menggunakan statistik deskriptif dengan urutan sebagai berikut. Pertama data hasil self-assessment di tabulasi oleh tim peneliti. Kedua pembersihan data yang tidak lengkap dan "aneh". Ketiga pengecekan data melalui fasilitas excel untuk memastikan ada data yang terlewat. Keempat melakukan kategorisasi data berdasarkan kriteria internal dari masing-masing instrumen. Kelima menyajikan data kategorik dalam bentuk grafik dan penejalasn naratifnya. Keenam melakukan exploratory factor analyses indicator teramati terhadap variable latent moral anak usia dini dengan menggunakan software Smart-PLS versi 3.8.2.

\section{HASIL DAN PEMBAHASAN}

Hasil ini menggambarkan persepsi guru tentang indikator teramati dari nilai moral anak usia dini. Salah satu alat bantu analisis pengukuran persepsi adalah Smart-PLS. Kriteria kelulusan indikator amatan terhadap variable latent adalah memiliki skor outer loadings minimal 0.7, composite reliability lebih besar dari 0.7, dan Average Variance Extracted lebih dari 0.5 (Joseph et al., 2021). Berikut diuraikan secara rinci masing-masing kriteria dari masingmasing konstruk nilai moral anak usia dini seperti pada Gambar 2.

Variable latent Adaptasi memiliki 6 indikator teramati, yaitu mengucapkan salam kepada teman (AD1), menjawab salam dari teman (AD2), bercakap-cakap dengan teman (AD3), mengekspresikan perasaan senang (AD4), mengkespresikan perasaan sedih (AD5), dan mengekspresikan perasaan antusias (AD6). Indikator teramati yang memenuhi syarat $>$ 0.7 adalah AD1 dan AD2. Oleh karena itu variable latent Adaptasi dapat diukur oleh indikator teramati mengucap dan menjawab salam dari teman. Kemampuan anak untuk bergaul dengan teman sebaya atau diterima dalam lingkungan pertemanan baru menandakan anak mampu menyesuaikan diri (Afiyah \& Saloom, 2018). Bertegur sapa dengan mengucap dan menjawab salam menandakan keakraban diantara anak satu dengan anak lainnya. 


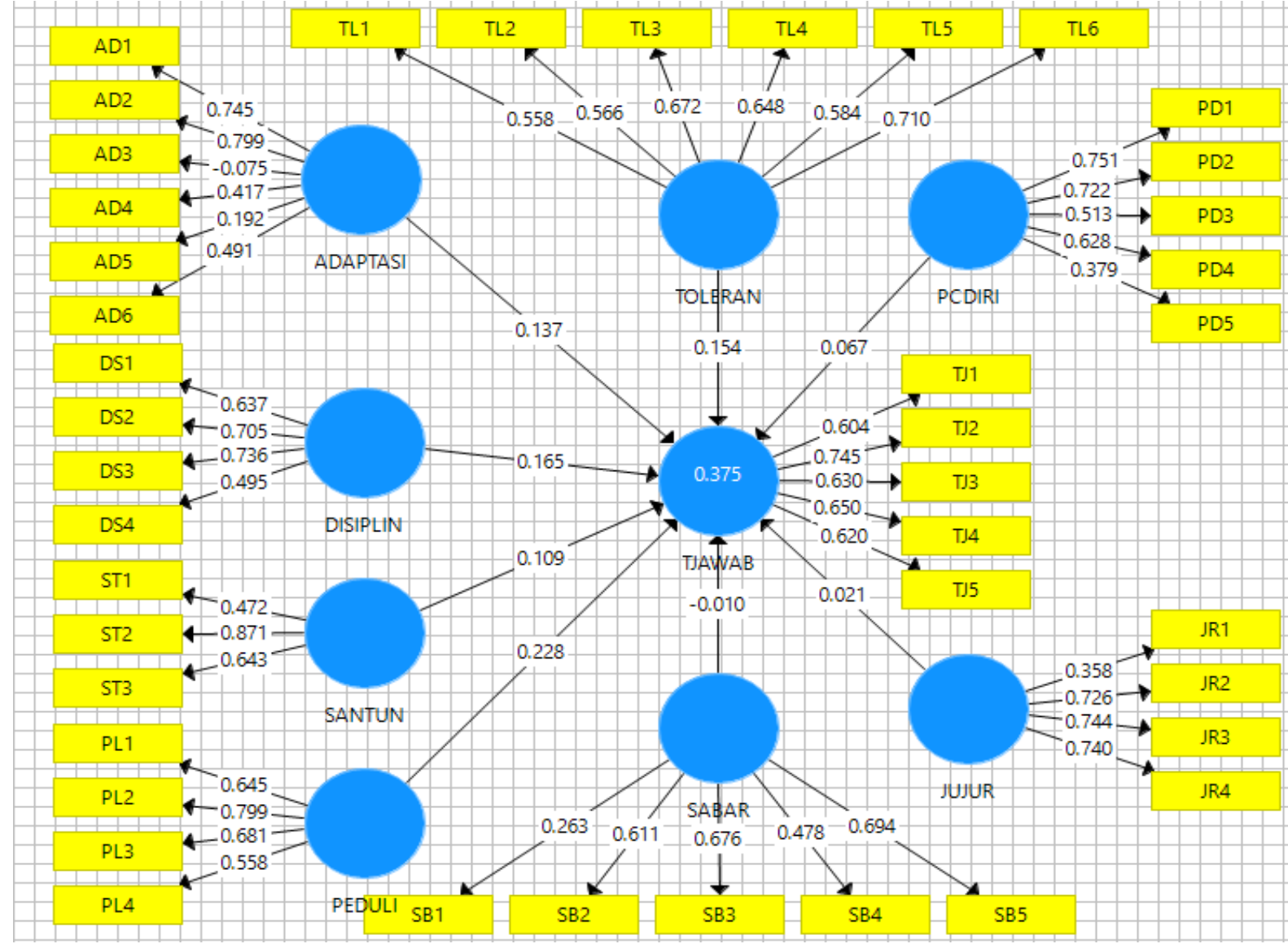

\section{Gambar 2. Diagram Jalur Indikator Teramati terhadap Variabel Latent Nilai Moral Anak Usia Dini} Tahap 1

Variable latent Disiplin memiliki 4 indikator teramati, yaitu melakukan kegiatan sesuai petunjuk (DS1), menaati tata tertib pergaulan (DS2), datang ke lokasi kegiatan tepat waktu (DS3), dan membuang sampah pada tempatnya (DS4). Indikator teramati yang memenuhi syarat $>0.7$ adalah DS2 dan DS3. Oleh karena itu variable latent Disiplin dapat diukur oleh indikator teramati menaati tata tertib dan menepati janji. Kedua indikator tersebut merupakan saripati dari disiplin, yaitu kemampuan mengendalikan diri dalam proses interkasi sosial (Pramono et al., 2018).

Variable latent Jujur memiliki 4 indikator teramati, yaitu meminjam barang milik teman atas seizinnya (JR1), menceritakan sesuatu sesuai dengan apa yang dilihatnya (JR2), berbuat sesuatu sesuai dengan ucapannya (JR3), menilai sesuatu secara apa adanya (JR4). Indikator teramati yang memenuhi syarat $>0.7$ adalah JR2, JR3, dan JR4. Oleh karena itu variable latent Jujur dapat diukur oleh indikator teramati bercerita apa adanya, berbuat apa adanya, dan menilai sesuatu apa adanya. Indikator kejujuran ini tidak diungkapkan dengan memadai mengenai substansinya dalam penelitian tentang kejujuran anak (Ansori, 2021). Temuan penelitian ini mengofirmasi subtansi kejujuran anak usia dini.

Variable latent Percaya diri memiliki 5 indikator teramati, yaitu berinisiatif untuk membuat kegiatan bersama teman (PD1), mau menceritakan pengalaman belajar hari ini (PD2), mau berpendapat tentang sesuatu yang disukainya (PD3), mau menerima saran teman untuk perbaikan hasil karya (PD4), menjawab pertanyaan teman dengan suara jelas (PD5). Indikator teramati yang memenuhi syarat $>0.7$ adalah PD1 dan PD2. Oleh karena itu variable latent Percaya Diri dapat diukur oleh indikator teramati inisiatif dan berbagi pengalaman belajar dengan teman lain. Temuan ini memperkuat indikator percaya diri yang dirumuskan oleh hasil penelitian (Fransisca et al., 2020). 
Variable latent Peduli memiliki 4 indikator teramati, yaitu menawarkan bantuan kepada teman (PL1), mau berbagi sesuatu dengan teman (PL2), memungut sampah yang tercecer dan menyimpan pada tempatnya (PL3), dan menggunakan manfaat barang secukupnya. Indikator teramati yang memenuhi syarat $>0.7$ adalah PL2. Oleh karena itu variable latent Peduli dapat diukur oleh indikator teramati berbagi sesuatu (makanan/alat belajar) dengan teman lain. Peduli kepada lingkungan sekitar termasuk manusia di dalamnya merupakan nilai moral universal yang menjunjung tinggi martabat ciptaan Tuhan. Anak-anak yang dibiasakan berbagi makanan maupun alat belajar dengan teman lain, akan tumbuh menjadi manusia yang memiliki kepedulian sosial (Marietta, 2019).

Variable latent Sabar memiliki 5 indikator teramati, yaitu dapat menunda pemuasan keinginan seketika (SB1), dapat menahan emosi ketika kesal (SB2), mau mendengarkan penjelasan dari orang lain (SB3), mengalah dari teman yang menyebalkan (SB4), dan bersedia antri sesuai giliran (SB5). Indikator teramati yang memenuhi syarat $>0.7$ adalah tidak ada sama sekali. Oleh karena itu variable latent Sabar tidak dapat diukur oleh kelima indikator teramati seperti yang dirumuskan dari kajian teori. Temuan ini bertolak belakang dengan hasil temuan pembiasaan disiplin melalui pembiasaaan yang dilakukan oleh (Lombu \& Suprihatin, 2020). Oleh karena itu perlu ditinjau ulang defnisi konseptual tentang sabar.

Variable latent Santun memiliki 3 indikator teramati, yaitu tidak menyela pembicaraan teman (ST1), bertutur kata baik kepada teman (ST2), menunjukkan gestur tubuh menghormati teman (ST3). Indikator teramati yang memenuhi syarat $>0.7$ adalah ST2. Oleh karena itu variable latent Santun dapat diukur oleh indikator teramati bertutur kata baik kepada teman lain. Temuan ini diperkuat hasil temuan penelitian kesantunan yang dilakukan oleh (Putrihapsari \& Dimyati, 2021). Inti kesantunan terletak pada komunikasi yang produktif antara anak dengan guru atau orang tuanya.

Variable latent Tanggung jawab memiliki 5 indikator teramati, yaitu meletakkan sesuatu pada tempatnya (TJ1), merapikan alat-alat kerja setelah digunakan (TJ2), cuci tangan sebelum kegiatan (TJ3), cuci tangan setelah kegiatan (TJ4), dan membersihkan tempat kerja setelah digunakan (TJ5). Indikator teramati yang memenuhi syarat $>0.7$ adalah TJ2. Oleh karena itu variable latent Tanggung jawab dapat diukur oleh indikator teramati merapikan alat setelah digunakan. Temuan ini diperkuat oleh hasil penelitian (Halimatussadiah et al., 2017) yang merumuskan lima indikator tanggung jawab anak, salah satunya adalah anak merapikan alat setelah digunakan.

Variable latent Toleran memiliki 6 indikator teramati, yaitu bekerja dengan teman tanpa pilih-pilih (TL1), tidak memaksakan keinginan kepada teman (TL2), tidak mengejek teman yang berbeda pendapat (TL3), mau mendengarkan pendapat teman lain (TL4), menghargai hak milik teman (TL5), dan menghargai hasil karya teman (TL6). Indikator teramati yang memenuhi syarat $>0.7$ adalah TL6. Oleh karena itu variable latent Toleran dapat diukur oleh indikator teramati menghargai hasil karya teman. Penghargaan anak terhadap karya teman lain menjadi penanda anak terbuka dengan kenyataan yang berbeda dengan dirinya, dan tidak membandingkan dirinya dengan orang lain, lalu mengejek orang lain yang berbeda dari dirinya (Tisnawati, 2019).

Berdasarkan hasil analisis outer loadings dari 42 indikator teramati dan 9 variable latent nilai moral anak usia dini (Tabel 1), maka ditemukan 13 indikator teramati dan 8 variable latent yang memenuhi syarat untuk analisis lanjutan (Tabel 2). Kedelapan variable latent tersebut ialah Adaptasi, Disiplin, Jujur, Percaya Diri, Peduli, Santun, Tanggung Jawab, dan Toleran, sedangkan variable latent sabar tidak memiliki indikator teramati yang di atas 0.7 skor outer loadings.

Berdasarkan hasil analisis skor outer loadings masing-masing indikator teramati dari 8 variabel latent nilai moral anak, maka ada 1 yang tidak memenuhi syarat 0.7 , yaitu indikator teramati JR3 untuk variable latent Jujur. Oleh karena itu, dilakukan analisis ulang dengan 12 indikator teramati yang memenuhi syarat $>0.7$ (Joseph et al., 2021) skor outer loadings dan tetap dengan 8 variable latent nilai moral anak. 
Tabel 1. Outer Loadings Nilai Moral Anak Usia Dini Tahap 1

\begin{tabular}{|c|c|c|c|c|c|c|c|c|c|}
\hline Indikator & ADAPTASI & DISIPLIN & JUJUR & PCDIRI & PEDULI & SABAR & SANTUN & TJAWAB & TOLERAN \\
\hline AD1 & 0,745 & & & & & & & & \\
\hline AD2 & 0,799 & & & & & & & & \\
\hline AD3 & $-0,075$ & & & & & & & & \\
\hline AD4 & 0,417 & & & & & & & & \\
\hline AD5 & 0,192 & & & & & & & & \\
\hline AD6 & 0,491 & & & & & & & & \\
\hline DS1 & & 0,637 & & & & & & & \\
\hline DS2 & & 0,705 & & & & & & & \\
\hline DS3 & & 0,736 & & & & & & & \\
\hline DS4 & & 0,495 & & & & & & & \\
\hline JR1 & & & 0,358 & & & & & & \\
\hline JR2 & & & 0,726 & & & & & & \\
\hline JR3 & & & 0,744 & & & & & & \\
\hline JR4 & & & 0,740 & & & & & & \\
\hline PD1 & & & & 0,751 & & & & & \\
\hline PD2 & & & & 0,722 & & & & & \\
\hline PD3 & & & & 0,513 & & & & & \\
\hline PD4 & & & & 0,628 & & & & & \\
\hline PD5 & & & & 0,379 & & & & & \\
\hline PL1 & & & & & 0,645 & & & & \\
\hline PL2 & & & & & 0,799 & & & & \\
\hline PL3 & & & & & 0,681 & & & & \\
\hline PL4 & & & & & 0,558 & & & & \\
\hline SB1 & & & & & & 0,263 & & & \\
\hline SB2 & & & & & & 0,611 & & & \\
\hline SB3 & & & & & & 0,676 & & & \\
\hline SB4 & & & & & & 0,478 & & & \\
\hline SB5 & & & & & & 0,694 & & & \\
\hline ST1 & & & & & & & 0,472 & & \\
\hline ST2 & & & & & & & 0,871 & & \\
\hline ST3 & & & & & & & 0,643 & & \\
\hline TJ1 & & & & & & & & 0,604 & \\
\hline TJ2 & & & & & & & & 0,745 & \\
\hline TJ3 & & & & & & & & 0,630 & \\
\hline TJ4 & & & & & & & & 0,650 & \\
\hline TJ5 & & & & & & & & 0,620 & \\
\hline TL1 & & & & & & & & & 0,558 \\
\hline TL2 & & & & & & & & & 0,566 \\
\hline TL3 & & & & & & & & & 0,672 \\
\hline TL4 & & & & & & & & & 0,648 \\
\hline TL5 & & & & & & & & & 0,584 \\
\hline TL6 & & & & & & & & & 0,710 \\
\hline
\end{tabular}


Tabel 2. Outer Loadings Nilai Moral Anak Usia Dini Tahap 2

\begin{tabular}{|c|c|c|c|c|c|c|c|c|}
\hline Indikator & ADAPTASI & DISIPLIN & JUJUR & PCDIRI & PEDULI & SANTUN & TJAWAB & TOLERAN \\
\hline AD1 & 0,838 & & & & & & & \\
\hline AD2 & 0,959 & & & & & & & \\
\hline DS2 & & 0,792 & & & & & & \\
\hline DS3 & & 0,832 & & & & & & \\
\hline JR2 & & & 0,817 & & & & & \\
\hline JR3 & & & 0,663 & & & & & \\
\hline JR4 & & & 0,717 & & & & & \\
\hline PD1 & & & & 0,737 & & & & \\
\hline PD2 & & & & 0,897 & & & & \\
\hline PL2 & & & & & 1,000 & & & \\
\hline ST2 & & & & & & 1,000 & & \\
\hline TJ2 & & & & & & & 1,000 & \\
\hline TL6 & & & & & & & & 1,000 \\
\hline
\end{tabular}

Hasil analisisnya diperoleh indikator teramati untuk variable latent Adaptasi berjumlah dua (AD1, AD2), Disiplin berjumlah dua (DS2, DS3), Jujur berjumlah dua (JR2, JR4), Percaya diri berjumlah dua (PD1, PD2), Peduli berjumlah satu (PL2), Santun berjumlah satu (ST2), Tanggung jawab berjumlah satu (TJ2), dan Toleran berjumlah satu (TL6) seperti pada Tabel 3. Keseluruhan indikator ini sudah teruji validitas dan reliablitasnya untuk masingmasing konstruk moral adaptasi, disiplin, jujur, percaya diri, peduli, santun, tanggung jawab, dan toreransi.

Tabel 3. Outer Loadings Nilai Moral Anak Usia Dini Tahap 3

\begin{tabular}{|c|c|c|c|c|c|c|c|c|}
\hline Indikator & ADAPTASI & DISIPLIN & JUJUR & PCDIRI & PEDULI & SANTUN & TJAWAB & TOLERAN \\
\hline AD1 & 0,838 & & & & & & & \\
\hline AD2 & 0,959 & & & & & & & \\
\hline DS2 & & 0,792 & & & & & & \\
\hline DS3 & & 0,832 & & & & & & \\
\hline JR2 & & & 0,902 & & & & & \\
\hline JR4 & & & 0,731 & & & & & \\
\hline PD1 & & & & 0,737 & & & & \\
\hline PD2 & & & & 0,897 & & & & \\
\hline PL2 & & & & & 1,000 & & & \\
\hline ST2 & & & & & & 1,000 & & \\
\hline TJ2 & & & & & & & 1,000 & \\
\hline TL6 & & & & & & & & 1,000 \\
\hline
\end{tabular}

Skor composite reliability kedelapan variable latent sudah memenuhi syarat $>0.7$ dan demikian pula skor average variance exstaracted sudah memenuhi syarat $>0.5$ (Joseph et al., 2021) sehingga dapat disimpulkan masing-masing variable latent memiliki convergent validity yang kuat, baik itu adaptasi, disiplin, jujur, percaya diri, peduli, santun, tanggung jawab, maupun toleran.

Secara grafis tersaji skor composite reliability untuk masing-masing latent variable berturut-turut sebagai berikut: peduli sebesar 0,895, disiplin sebesar 0,795, jujur sebesar 0,803, percaya diri sebesar 0,804 , peduli sebesar 1,000 , santun sebesar 1,000, tanggung jawab sebesar 
1,000, dan toleran sebesar 1,000. Demikian pula untuk score average variance extracted (AVE) tersaji berturut-turut sebagai berikut: peduli sebesar 0,811, disiplin sebesar 0,660, jujur sebesar 0,674 , percaya diri sebesar 0,674 , peduli sebesar 1,000, santun sebesar 1,000, tanggung jawab sebesar 1,000, dan toleran sebesar 1,000 seperti pada Tabel 4. Berdasarkan kedua kriteria tersebut, maka dapat disimpulkan bahwa masing-masing variable latent nilai moral anak telah memenuhi syarat Convergent Validity (Joseph et al., 2021) seperti pada Gambar 3 dan 4.

Tabel 4. Composite Reliability dan AVE Nilai Moral Anak Usia Dini

\begin{tabular}{|c|c|c|}
\hline Variable Latent & Composite Reliability & Average Variance Extracted (AVE) \\
\hline ADAPTASI & 0,895 & 0,811 \\
\hline DISIPLIN & 0,795 & 0,660 \\
\hline JUJUR & 0,803 & 0,674 \\
\hline PCDIRI & 0,804 & 0,674 \\
\hline PEDULI & 1,000 & 1,000 \\
\hline SANTUN & 1,000 & 1,000 \\
\hline TJAWAB & 1,000 & 1,000 \\
\hline TOLERAN & 1,000 & 1,000 \\
\hline
\end{tabular}

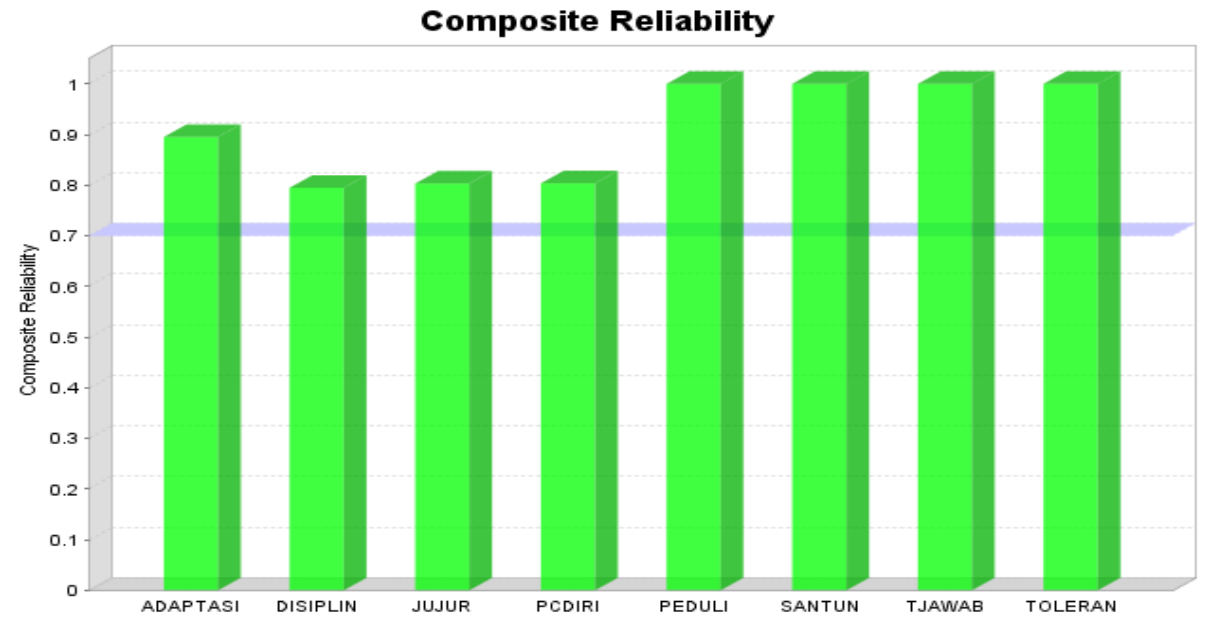

Gambar 3. Composite Reliability $>0.7$ sebagai Syarat Convergent Validity Terpenuhi

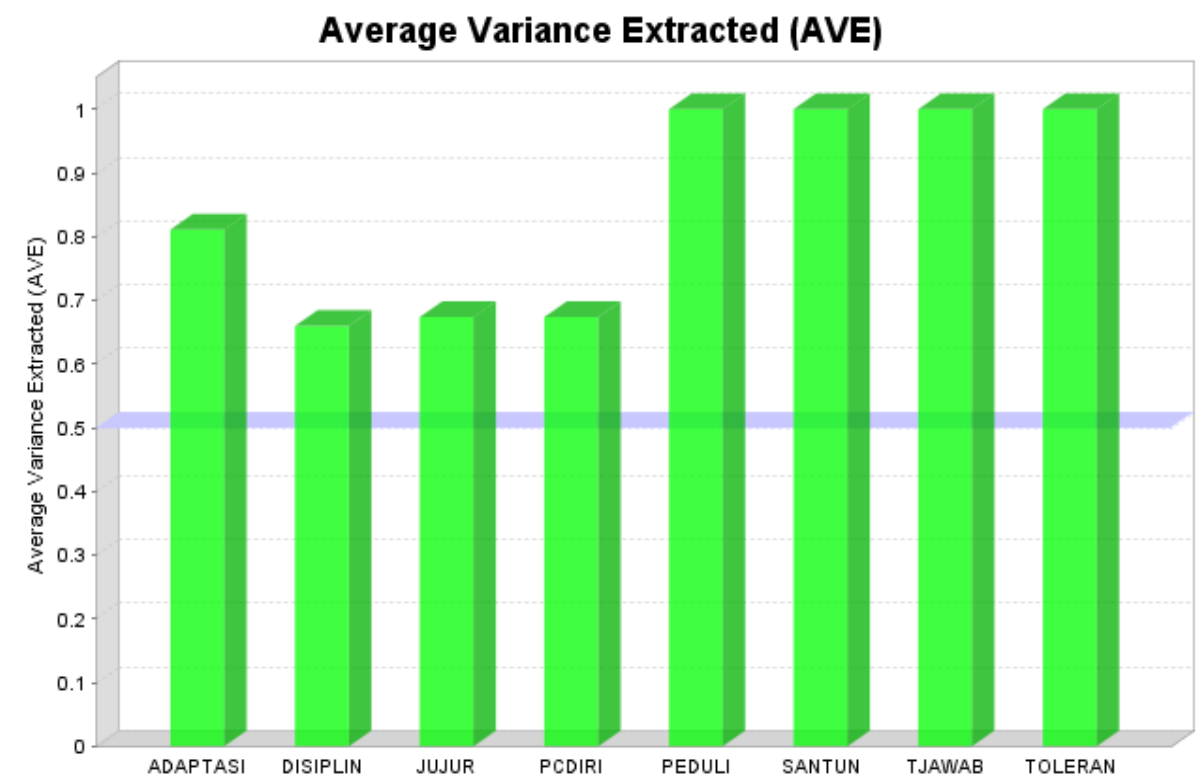

Gambar 4. Average Variance Extracted (AVE) $>0.5$ sebagai Syarat Convergent Validity Terpenuhi 
Skor discriminant validity tertinggi akan mengelompok pada crossloading variable latent (Joseph et al., 2021). Misalnya skor crossloading variable laten adaptasi dengan indikator teramati AD1 dan AD2 adalah skor tertinggi dibandingkan skor crossloading variable latent dengan indikator teramati seperti Disiplin, Jujur, Percaya Diri, Peduli, Santun, Tanggung jawab, dan Toleran. Demikian seterusnya untuk masing-masing variable latent dan indikator teramatinya seperti di Tabel 5.

Tabel 5. Discriminant Validity Nilai Moral Anak Usia Dini

\begin{tabular}{|c|c|c|c|c|c|c|c|c|}
\hline Indikator & ADAPTASI & DISIPLIN & JUJUR & PCDIRI & PEDULI & SANTUN & TJAWAB & TOLERAN \\
\hline AD1 & 0,838 & 0,213 & 0,104 & 0,064 & 0,198 & 0,146 & 0,149 & 0,117 \\
\hline AD2 & 0,959 & 0,285 & 0,122 & 0,012 & 0,262 & 0,285 & 0,285 & 0,095 \\
\hline DS2 & 0,302 & 0,792 & 0,127 & 0,127 & 0,401 & 0,353 & 0,329 & 0,083 \\
\hline DS3 & 0,166 & 0,832 & 0,156 & 0,137 & 0,314 & 0,419 & 0,363 & 0,235 \\
\hline JR2 & 0,113 & 0,168 & 0,902 & 0,298 & 0,148 & 0,121 & 0,188 & 0,092 \\
\hline JR4 & 0,094 & 0,112 & 0,731 & 0,217 & 0,241 & 0,205 & 0,119 & 0,167 \\
\hline PD1 & $-0,025$ & 0,093 & 0,283 & 0,737 & 0,229 & 0,171 & 0,106 & 0,176 \\
\hline PD2 & 0,061 & 0,164 & 0,255 & 0,897 & 0,296 & 0,119 & 0,162 & 0,173 \\
\hline PL2 & 0,261 & 0,437 & 0,220 & 0,323 & 1,000 & 0,406 & 0,379 & 0,232 \\
\hline ST2 & 0,259 & 0,477 & 0,184 & 0,168 & 0,406 & 1,000 & 0,349 & 0,305 \\
\hline TJ2 & 0,260 & 0,427 & 0,192 & 0,168 & 0,379 & 0,349 & 1,000 & 0,180 \\
\hline TL6 & 0,112 & 0,200 & 0,145 & 0,209 & 0,232 & 0,305 & 0,180 & 1,000 \\
\hline
\end{tabular}

Pembahasan

Proses uji validitas dan reliabilitas indikator teramati perilaku moral anak dari variable latentnya dilakukan dalam tiga tahap. Tahap pertama ada 42 indikator teramati dan 9 variable latent nilai moral anak usia dini. Berdasarkan kriteria skor outer loadings minimal 0.7 (Joseph et al., 2021), maka ditemukan 13 indikator teramati dan 8 variable latent yang memenuhi syarat untuk analisis tahap kedua. Kedelapan variable latent tersebut ialah Adaptasi, Disiplin, Jujur, Percaya Diri, Peduli, Santun, Tanggung Jawab, dan Toleran. Variable latent sabar tidak memiliki indikator teramati di atas 0.7 skor outer loadings sehingga tidak dianalisis pada tahap dua.

Tahap kedua ada 13 indikator teramati dari 8 variabel latent nilai moral anak. Hasil analisisnya ada satu indikator teramati JR3 untuk variable latent Jujur itu gugur. Oleh karena itu, dilakukan analisis ulang dengan 12 indikator teramati yang memenuhi syarat $>0.7$ (Joseph et al., 2021) skor outer loadings dan tetap dengan 8 variable latent nilai moral anak pada tahap ketiga.

Tahap ketiga diperoleh indikator teramati untuk variable latent Adaptasi berjumlah dua (AD1, AD2), Disiplin berjumlah dua (DS2, DS3), Jujur berjumlah dua (JR2, JR4), Percaya diri berjumlah dua (PD1, PD2), Peduli berjumlah satu (PL2), Santun berjumlah satu (ST2), Tanggung jawab berjumlah satu (TJ2), dan Toleran berjumlah satu (TL6). Keseluruhan indikator ini sudah teruji validitas dan reliablitasnya untuk masing-masing konstruk moral adaptasi, disiplin, jujur, percaya diri, peduli, santun, tanggung jawab, dan toreransi.

Skor composite reliability kedelapan variable latent sudah memenuhi syarat $>0.7$ dan demikian pula skor average variance exstaracted sudah memenuhi syarat $>0.5$ (Joseph et al., 2021) sehingga dapat disimpulkan masing-masing variable latent memiliki convergent validity yang kuat.

Skor discriminant validity tertinggi akan mengelompok pada crossloading variable latent (Joseph et al., 2021). Misalnya skor crossloading variable laten adaptasi dengan indikator teramati AD1 dan AD2 adalah skor tertinggi dibandingkan skor crossloading variable latent 
dengan indikator teramati seperti Disiplin, Jujur, Percaya Diri, Peduli, Santun, Tanggung jawab, dan Toleran, serta demikian seterusnya untuk masing-masing variable latent dan indikator teramati.

Indikator teramati dari Adaptasi adalah bergaul dengan teman sebaya dan diterima dalam lingkungan pertemanan baru. Temuan ini merevisi indikator teramati dari adaptasi versi (Meinarno, E, 2011) berjumlah enam menjadi hanya dua saja yang valid dan reliable (Amaliah \& Prasetyo, 2021).

Indikator teramati dari Disiplin adalah pengendalian diri anak dalam proses interkasi sosial dengan lingkungannya. Disiplin merupakan perilaku anak melakukan kegiatan sesuai dengan aturan dan instruksi yang diberikan oleh guru maupun dalam rutinitas (kebiasaan) yang ada didalam kelas ataupun lingkungan sekolah (Aulina, 2013). Temuan ini merevisi indikator teramati dari disiplin menurut (Pramono et al., 2018) yang semula empat menjadi dua saja yang valid dan reliable, yaitu taat pada aturan dan datang ke sekolah tepat waktu (Utami, 2021).

Indikator teramati dari Jujur adalah anak bercerita, berbuat, dan menilai sesuatu apa adanya. Jujur dapat ditandai dengan anak meminta izin ketika meminjam barang dan mengembalikan barang yang dipinjam serta tidak membawa pulang mainan yang bukan miliknya (Azizah, R.; Putri, N. R.; Rahmadini, T. A.; \& Lokeswara, 2019). Indikator kejujuran ini tidak diungkapkan dengan memadai mengenai substansinya dalam penelitian tentang kejujuran anak oleh (Ansori, 2021). Temuan penelitian ini mengofirmasi subtansi kejujuran anak usia dini, yaitu berkata dan berpendapat tentang sesuatu apa adanya seperti yang dialami anak.

Indikator teramati dari Percaya diri memiliki lima indikator teramati dan setelah diuji validitas dan reliabilitasnya menjadi dua, yaitu inisiatif dan berbagi pengalaman belajar dengan teman lain. Temuan ini memperkuat indikator percaya diri yang dirumuskan oleh hasil penelitian (Fransisca et al., 2020). Percaya diri anak dapat dideskripsikan dengan anak berinisiatif dan berani untuk menceritakan pengalaman, pendapat, hasil karya dan menjawab pertanyaan yang diberikan. Anak dapat mengerjakan tugas dengan optimis, dan mudah berinteraksi dengan teman sebaya atau orang yang berada di lingkungannya (Fransisca et al., 2020).

Indikator teramati dari Peduli berjumlah satu dari empat indikator teramati pada tahap pertama. Variable latent Peduli dapat diukur oleh indikator teramati berbagi sesuatu (makanan/alat belajar) dengan teman lain. Peduli kepada lingkungan sekitar termasuk manusia di dalamnya merupakan nilai moral universal yang menjunjung tinggi martabat ciptaan Tuhan. Anak-anak yang dibiasakan berbagi makanan maupun alat belajar dengan teman lain, akan tumbuh menjadi manusia yang memiliki kepedulian sosial (Marietta, 2019).

Indikator teramati dari Santun berjumlah satu dari tiga indikator teramati pada tahap pertama, yaitu bertutur kata baik kepada teman. Temuan ini diperkuat hasil temuan penelitian kesantunan yang dilakukan oleh (Putrihapsari \& Dimyati, 2021). Inti kesantunan terletak pada komunikasi yang produktif antara anak dengan guru atau orang tuanya.

Indikator teramati dari Tanggung jawab berjumlah satu dari lima indikator teramati pada tahap satu, yaitu merapikan alat-alat kerja setelah digunakan. Temuan ini diperkuat oleh hasil penelitian (Halimatussadiah et al., 2017) yang merumuskan lima indikator tanggung jawab anak, salah satunya adalah anak merapikan alat setelah digunakan.

Indikator teramati dari Toleran berjumlah satu dari enam indikator teramati pada tahap pertama, yaitu menghargai hasil karya teman. Penghargaan anak terhadap karya teman lain menjadi penanda anak terbuka dengan kenyataan yang berbeda dengan dirinya, dan tidak membandingkan dirinya dengan orang lain, lalu mengejek orang lain yang berbeda dari dirinya (Tisnawati, 2019). 


\section{SIMPULAN}

Nilai moral anak usia dini terdiri dari adaptasi, disiplin, jujur, percaya diri, peduli, santun, tanggung jawab, dan toleran. Adaptasi anak itu bergaul dengan teman sebaya atau diterima dalam lingkungan pertemanan baru. Disiplin itu mengendalikan diri anak dalam proses interkasi sosial. Substansi kejujuran itu bercerita, berbuat, dan menilai sesuatu apa adanya. Percaya diri dicirikan oleh inisiatif dan berbagi pengalaman belajar dengan teman lain. Anak-anak yang berbagi makanan/alat belajar dengan teman lain adalah init peduli. Kesantunan terletak pada komunikasi yang produktif antara anak dengan guru. Tanggung jawab diamati melaui aktivitas anak merapikan alat setelah digunakan. Penghargaan anak terhadap karya teman lain menjadi penanda anak terbuka dengan kenyataan yang berbeda dengan dirinya.

\section{UCAPAN TERIMA KASIH}

Saya mengucapkan terima kasih kepada Kepala Dinas Pendidikan, Pemuda, \& Olah Raga Kabupaten Gunung Kidul dan Staf yang telah mengizinkan penulis melakukan penelitian di Lembaga PAUD/TK di Gunung Kidul. Juga saya mengucapkan terima kepada Dekan Fakultas Ilmu Pendidikan Universitas Negeri Yogyakarta dan jajaran pimpinan yang telah menyetujui pendanaan penelitian dan publikasi artikel ini.

\section{DAFTAR PUSTAKA}

Afiyah, S., \& Saloom, G. (2018). Social support of self-efficacy friends in self-adjustment of new santri. Dialog, 41(2), 139-281. https://doi.org/10.47655/dialog.v41i2.309

Amaliah, S., \& Prasetyo, T. (2021). Program pondok ceria sarana belajar menyenangkan anakanak kampung Pancawati masa adaptasi kebiasaan baru. Educivilia, 2(1), 43. https://doi.org/10.30997/ejpm.v2i1.3614

Ansori, Y. Z. (2021). Strategi pendidik dalam menumbuhkan karakter jujur pada anak usia dini. Jurnal Obsesi : Jurnal Pendidikan Anak Usia Dini, 6(1), 261-270. https://doi.org/10.31004/obsesi.v6i1.1208

Apriliani, E. I., Purwanti, K. Y., \& Riani, R. W. (2020). Peningkatan kesantunan bahasa anak usia dini melalui media pembelajaran interaktif budaya jawa. Jurnal Obsesi : Jurnal Pendidikan Anak Usia Dini, 5(1), 150. https:/ / doi.org/10.31004/obsesi.v5i1.319

Aulina, C. N. (2013). Penanaman disiplin pada anak usia dini. Jurnal Pedagogia, 2.1. https://doi.org/10.21070/pedagogia.v2i1.45

Azizah, R.; Putri, N. R.; Rahmadini, T. A.; \& Lokeswara, M. E. (2019). Bohong vs jujur. Mizan. BPKP. (2021). Profile kabupaten gunungkidul. http://www.bpkp.go.id/diy/konten/835/profil-kabupaten-gunungkidul

Disdikpora. (2021). Dinas pendidikan, pemuda, dan olahraga gunungkidul. https://pendidikan.gunungkidulkab.go.id/home/files/5\#

Fransisca, R., Wulan, S., \& Supena, A. (2020). Meningkatkan percaya diri anak dengan permainan ular tangga edukasi. Jurnal Obsesi : Jurnal Pendidikan Anak Usia Dini, 4(2), 630. https:// doi.org/10.31004/obsesi.v4i2.405

Fuad, N. (2015). Penanaman toleransi beragama pada anak melalui pendidikan. Societas Dei: $\begin{array}{llll}\text { Jurnal Agama Dan } & \text { Masyarakat, }\end{array}$ https://doi.org/10.33550/sd.v2i1.61

Ghozali, M. S. I. (2021). Sabar sebagai terapi penyakit hati menurut al-Ghazali. Osf.Io. https://doi.org/10.31219/osf.io/9phxn

Halimatussadiah, H., Edi, R., \& Leli, H. (2017). Pengembangan karakter tanggung jawab anak melalui kegiatan cooking class. Cakrawala Dini, 8. https://doi.org/10.17509/cd.v8i1.10552 
Hidayati, N. L., \& Widyana, R. (2021). Pelatihan regulasi emosi untuk menurunkan perilaku perundungan pada remaja pelaku perundungan. Jurnal Psikologi, 14(1), 25-37. https:// doi.org/10.35760/psi.2021.v14i1.3352

Joseph, F. H. J., Hult, G. T. M., Ringle, C. M., Sarstedt, M., Danks, N. P., \& Ray, S. (2021). Partial least squares structural equation modeling (PLS-SEM) using R. In Handbook of Market Research. Springer Switzerland. https:// doi.org/10.1007/978-3-319-05542-8_15-2

Peraturan menteri pendidikan \& kebudayaan RI tentang kurikulum 2013 pendidikan anak usia dini, Pub. L. No. 146, 7 (2014).

Lombu, S. K., \& Suprihatin, E. (2020). Studi tentang perkembangan kesabaran Anak 4-5 Tahun melalui budaya antre di TK bina kasih terpadu. EDULEAD: Journal of Christian Education and Leadership, 1(2), 114-128. https://doi.org/10.47530/edulead.v1i2.31

Marietta, A. D. (2019). Meningkatkan karakter peduli lingkungan melalui kegiatan berkebun pada anak kelompok B RA perwanida 4 jakabaring palembang. PERNIK: Jurnal Pendidikan Anak Usia Dini, 2(1), 52-65. https://doi.org/10.31851/pernik.v2i2.4088

Masrukhan, A. (2016). Pelaksanaan pendidikan karakter peduli sosial di sd negeri 4 kotagede yogyakarta. Jurnal Pendidikan Guru Sekolah Dasar, 29.

Meinarno, E, A. (2011). Manusia dalam kebudayaan masyarakat (A. E. Meinarno (ed.)). Salemba Humanika.

Mumtaza, F. A. (2018). 70 doa harian anak. Elex Media Komputindo. https:/ / elexmedia.id/

Nugroho, A. S., \& Mawardi, M. (2021). Pengembangan instrumen penilaian sikap tanggungjawab dalam pembelajaran tematik di sekolah dasar. Jurnal Basicedu, 5(2), 808-817. https:// doi.org/10.31004/basicedu.v5i2.825

Pramono, D., Risnawati, A., \& Siliwang, I. (2018). Meningkatkan kedisiplinan anak usia dini melaluilLatihan pembiasaan penggunaan toilet di KB al-hidayah insan mandiri kabupaten bandung. Jurnal Obsesi: Jurnal Pendidikan Anak Usia Dini, 2(1), 64-69. https:// doi.org/10.31004/obsesi.v2i1.8

Putrihapsari, R., \& Dimyati, D. (2021). Penanaman sikap sopan santun dalam budaya jawa pada anak usia dini. Jurnal Obsesi : Jurnal Pendidikan Anak Usia Dini, 5(2), 2059-2070. https:// doi.org/10.31004/obsesi.v5i2.1022

Ratu Balqis, R. (2021). Faktor-faktor yang mempengaruhi perilaku adaptif anak usia dini. Auladuna: Jurnal Prodi Pendidikan Guru Madrasah Ibtidaiyah, 3(1), 85-90. https:// doi.org/10.36835/au.v3i1.511

Soleh, M. (2018). Kumpulan doa sehari-hari untuk pembentukan karakter anak. Caremedia Communication. http:/ / caremedia.web.id/

Tisnawati, N. (2019). Pendidikan multikultural sebagai upaya penguatan nilai karakter toleransi pada anak usia dini di perumahan PNS kota metro. J-Sanak_Jurnal Kajian Anak, 1(1), 37-52. https:// doi.org/10.24127/j-sanak.v1i01.10

Utami, F. (2021). Pengasuhan keluarga terhadap perkembangan karakter disiplin anak usia dini. Jurnal Obsesi: Jurnal Pendidikan Anak Usia Dini, 5(2), 1777-1786. https:// doi.org/10.31004/obsesi.v5i2.985

Wijaya, E. (2020). Identifikasi dan intervensi gangguan belajar spesifik pada anak. Damianus: Journal of Medicine, 19(1), 70-79. https://doi.org/10.25170/djm.v19i1.1279 